\title{
Short-term respiratory exercise effects, different environments, pulmonary functional and physical capacity in elderly
}

\author{
Efeitos em curto prazo de exercícios respiratórios, diferentes \\ ambientes, capacidade funcional pulmonar e física em idosas
}

\author{
Mariel Dias Rodrigues ${ }^{[a, b]}$, Renatha Almeida Marquez ${ }^{[c]}$, Aldair Montagnini Neto ${ }^{[c]}$, \\ Nathany Souza Schafauser ${ }^{[\mathrm{a}]}$, Eliane Gouveia de Moraes Sanchez ${ }^{[\mathrm{c}]}$, \\ Patrícia Leão da Silva Agostinho ${ }^{[]^{*}}$
}

[a] Centro de Estudos Avançados e Formação Integrada (CEAFI), Goiânia, GO, Brazil

[b] Pontifícia Universidade Católica de Goiás (PUC Goiás), Goiânia, GO, Brazil

[c] Universidade Federal de Goiás (UFG), Jataí, GO, Brazil

\begin{abstract}
Introduction: Aging is often associated with reduced functional capacity (FC) and respiratory muscle strength (RMS). Objective: To verify the short-term aquatic and land-based respiratory exercise effects on RMS, pulmonary function, FC and palmar grip strength (PGS) in healthy elderly women. Methods: A blinded, randomized, controlled clinical trial was conducted. The sample was composed by 32 elderly women, randomized in two groups: Land-Based Group (LG), and Hydrotherapy Group (HG). Exercise program was performed in two weekly sessions (40 minutes each), during four weeks. Evaluations (anthropometry, manovacuometry and spirometry) were performed; FC by the 6-minute Walk Test (6MWT), and PGS test. All evaluations were performed before and after four-week intervention. Results: about RMS evaluation, there was an improvement in the Maximum Expiratory Pressure (MEP) values from $63.8 \pm 19$ to $74 \pm 20$
\end{abstract}

\footnotetext{
MDR: BS, e-mail: mari_fisio@outlook.com RAM: undergrad, e-mail: renathamarquez@hotmail.com AMN: undergrad, e-mail: montagnini.aldair@gmail.com NSS: BS, e-mail: nathany-92@hotmail.com EGMS: PhD, e-mail: egmfisio@gmail.com PLSA: PhD, e-mail: p.leao@hotmail.com
} 
( $\mathrm{p}=0.007$ ) of HG. LG had an increase in forced expiratory flow (FEF) between $25-75 \%$ of forced vital capacity (FEF $25-75 \%)$ from $82 \pm 29$ to $101 \pm 26(\mathrm{p}=0.04)$. There was no statistically significant PGS improvement and walking 6MWT distance in both groups. HG presented lower values of Initial Heart Rate and Diastolic Blood Pressure, both pre $(p=0.006)$ and post 6MWT $(p=0.041)$. Conclusion: It may be suggested that, in the short-term, the respiratory exercise aquatic protocol has positive effects on the MEP and cardiovascular parameters in elderly.

Keywords: Elderly. Physical Exercise. Hydrotherapy. Respiratory Muscles.

\section{Resumo}

Introdução: $O$ envelhecimento frequentemente está associado à redução da capacidade funcional (CF) $e$ força muscular respiratória (FMR). Objetivo: Verificar os efeitos em curto prazo de exercícios respiratórios realizados em ambiente aquático e no solo sobre a FMR, função pulmonar, CF e força de preensão palmar (FPP) em idosas saudáveis. Métodos: Foi realizado um ensaio clínico, cego, randomizado controlado. A amostra contou com 32 idosas, randomizadas em dois grupos: Grupo Solo (GS), e Grupo Hidroterapia (GH). $O$ programa de exercício foi realizado em duas sessões semanais de 40 minutos cada, durante quatro semanas. Foram realizadas avaliações (antropometria, manovacuometria e espirometria); CF pelo Teste de Caminhada de 6 minutos (TC6), e teste de FPP. Todas as avaliações foram realizadas antes e após quatro semanas de intervenção. Resultados: A avaliação da FMR demonstrou que houve uma melhora nos valores da Pressão Expiratória Máxima (PEmáx) de 63,8 \pm 19 para $74 \pm 20$ ( $p=0,007)$ do GH. O GS apresentou aumento no fluxo expiratório forçado entre $25-75 \%$ da capacidade vital forçada (FEF 25-75\%) de $82 \pm 29$ para $101 \pm 26$ $(p=0,04)$. Não foi observado melhora estatisticamente significativa na FPP e na distância caminhada no TC6 em ambos os grupos. O GH apresentou menores valores de Frequência Cardíaca inicial e de Pressão Arterial Diastólica tanto pré $(p=0,006)$ como pós TC6 $(p=0,041)$. Conclusão: Pode-se sugerir que, em curto prazo, o protocolo de exercícios respiratórios em ambiente aquático tem efeitos positivos sobre a PEmáx e parâmetros cardiovasculares de idosas.

Palavras-chave: Idosos. Exercício Físico. Hidroterapia. Músculos Respiratórios.

\section{Introduction}

Brazilian population aging rate has increased considerably: about $9 \%$ of the population is elderly. Studies estimate that, by 2025, Brazil is the sixth country with the highest percentage of elderly people in the world [1].

Aging is characterized by several negative functional and structural organism changes, which happening progressively as the age advances, and affecting the motor skills performance, making difficult for adapting to the environment, causing psychological and social changes [2].

Also, there is a skeletal muscle strength decline, including respiratory muscle strength (RMS), and promoting a decrease in chest compliance and the elastic recoil force of the lungs, interfering with physical and functional capacity for activities of daily living (ADL) in elderly [3,4]. These changes are clinically relevant, since the pulmonary functional capacity decrease is associated with morbidity and mortality rate increase in this population [5].

Aging is associated with a negative RMS and physical functional capacity impact; strategies are needed to promote prevention and treatment of this consequence. So, the physical exercise practice has demonstrated positive effects in this population $[6,7]$.

Performing physical exercises leads to increased flexibility, muscle strength, cooperates to perform $\mathrm{ADL}$, elevates self-esteem, reduces depression risk, helps social interaction, and improves psychological aging factors and RMS [8].

When the aquatic environment is related to an exercise program, several advantages are presented compared to land-based one, and this can be explained by the physiological environment effects. Buoyancy 
and hydrostatic pressure cause the respiratory system to work under a constant overload, and the soft tissues and joints complacency is improved by the elevated temperature [6].

However, several studies only cross-examined the aquatic training effects on RMS not comparing to traditional environment [7], or evaluated only the exercise protocols effects on inspiratory muscles on RMS [9], and not investigating the mixed breathing exercises program influence on the physical and pulmonary functional capacity in elderly, suggesting additional studies.

This study aimed at verifying the short-term aquatic and land-based respiratory exercise protocol effects on the functional pulmonary and physical capacity in healthy elderly women.

\section{Methods}

This is a four-week blinded, randomized, controlled clinical trial at Lar Vila Vida (Jataí city, Goiás state, Brazil). The study was according to Diretrizes e Normas Regulamentaras de Pesquisa Envolvendo Seres Humanos (Resolution 466/12, Conselho Nacional de Saúde) and was approved by the Universidade Federal de Goiás Research Ethics Committee (number 1.804.208).

The sample was composed by elderly women enrolled at Programa de Esporte e Lazer na Cidade (PELC) $(\mathrm{n}=64)$. Inclusion criteria were: subjects aged between 60 and 70 years, without cardiorespiratory diseases, non-smokers, and low physical activity level, as assessed by the Modified Baecke Questionnaire [10]. Exclusion criteria were: a height less than $1.45 \mathrm{~m}$, any open wound, contagious rash, infectious disease, severe cardiovascular disease, uncontrolled seizures history, colostomy bag or catheter use, tracheostomy tubes, gastrostomy and/or nasogastric, decreased orofacial control and hypotension or severe arterial hypertension.

Elderly were submitted to an anthropometric evaluation, physical activity level evaluation by the Modified Baecke Questionnaire [10], and answered a questionnaire about life habits, clinical history and skin conditions. After sorting, the elderly women were randomized in two experimental groups, using the UPGMA method [11]: land-based group (LS) for traditional exercises; hydrotherapy group (HG), for water exercises. For the randomization, the following variables were used: Body Mass Index (BMI), sex, age and physical activity level.

They were submitted to pulmonary functional capacity assessments that included spirometry and manovacuometry, and physical fitness evaluation (6MWT) and the palmar grip strength (PGS) measurement. Each test was performed by the same evaluator, who had no volunteer intervention group knowledge. All evaluations were performed before and after four-week intervention in order to evaluate possible changes in physiological parameters.

The pulmonary function evaluation used a portable spirometer of Clement Clarke International Ltda $^{\circledR}$ model One Flow Soft 1.4 (England). The subjects used a nasal clip in a sitting position with their heads in a neutral position, they were asked to take an inspiration up to the Total Pulmonary Capacity (TPC), pausing for up to three seconds after inspiration, then the mouthpiece was placed immediately on the tongue, between the teeth, closing the lips, being finally requested at the maximum expiration which should be sustained for at least six seconds. Three reproducible forced expiratory maneuvers were performed and the best value was selected according to Brazilian Society of Pulmonology and Phthisiology criteria [12].

Evaluated parameters were: Forced Expiratory Volume in one second (FEV1); Forced Vital Capacity (FVC); Relationship FEV1/FVC (FEV1/FVC); Peak of Expiratory Flow (PEF); Forced Expiratory Flow between 25 and $75 \%$ of the FVC (FEF 25-75\%). They are presented as a percentage of predicted, according to Knudson equation [13].

A GER-AR manovacuometer, model MV150/300, was used to measure the maximum inspiratory pressure (MIP) and maximal expiratory pressure (MEP), measured in -150 to $+150 \mathrm{~cm}$ of water, consisting of manometer, trachea, connector and mouthpiece. For measuring MIP, the patient used a nasal clip in a sitting position with the head in a neutral position. The lungs were then voided at the residual volume (RV), the nozzle was correctly positioned followed by a maximal inspiration up to the total pulmonary capacity (TPC) level, holding it for one second. Three maneuvers were performed, so that the highest recorded value was analyzed [14].

In order to measure MEP, the subject was asked to maximally inhale up to the TPC level, then with the nasal clip and the manovacuometer connection nozzle correctly positioned, the subject 
was asked to have a maximum expiration up to the RV level, holding it for a second. Three maneuvers were performed; the highest recorded value was analyzed [15]. A two-minute rest interval was established between the measures in order to prevent possible respiratory muscle fatigue avoiding altered results $[16,17]$. The maximum respiratory pressures results are presented in $\mathrm{cmH} 2 \mathrm{O}$.

Functional capacity assessment was performed using the six-minute walk test (6MWT) following the standardization described by the American Thoracic Society (ATS) [18]. The participants were instructed on how the test should be performed and asked to walk as fast as possible, and they were encouraged by the examiner for verbal stimulation every one minute. If the participants presented with very great respiratory discomfort, chest pain or intense muscular pain, they were instructed to reduce the speed or even interrupt the test. At the six-minute end, the distance covered was recorded. At test end, the subject remained at the place where the walking was completed, and the vital data of oxygen saturation (Sp02), respiratory rate (RR), blood pressure (BP), heart rate (HR) at the end, one and two minutes after the test and including the Borg Modified Perceived Scale [19], the same data was collected prior to test run.

For PGS evaluation, a SAEHAN ${ }^{\circledR}$ hydraulic hand dynamometer was used. The test was standardized following an instruction protocol, handling and patient positions [20]. The PGS assessment was performed with the subjects seated in a chair with a straight back without arm support, adducted shoulder and elbow flexed at $90^{\circ}$, forearm in a neutral position and wrist between $0^{\circ}$ and $30^{\circ}$ of extension and $0^{\circ}$ at $15^{\circ}$ of ulnar deviation, knee and hip flexed at $90^{\circ}$. The tests were performed three times in each hand (five-second each trial), always starting with the right hand, the highest value noted in $\mathrm{kg} / \mathrm{F}$ was used for analyzing [19].

The respiratory exercise protocol was based on three-phase model used by Pereira [21]:

Phase 1: Thoracic cavity mobility - the exercises started from hip and knees flexion and extension, reproducing the "crouch and lift" movement, as following:

Exercise 1 - Crouch and stand up, with hand on waist. Exercise 2 - Same as 1, associated with shoulder flexion.
Exercise 3 - Same as the 1st associated with shoulders abduction.

Exercise 4 - Shoulder flexion and inspiratory sighs. In all exercises, deep chest inspirations were requested (out of the water) and exhalations during chest immersion (at C7 level).

Phase 2: Endurance training for inspiratory muscles - semiflexed hips and knees positioning, with the thorax immersed to the shoulders, performing diaphragmatic breathing (anterior abdominal displacement at each inspiration), as follows:

Exercise 1 - Hip and semi-legged knees with hand rest on the abdominal region.

Exercise 2 - Same as the 1st associated with the horizontal shoulders abduction on the water surface during inspiration.

Exercise 3 - Same as the 1st associated with unilateral shoulder abduction, accompanied by lateral trunk flexion to contralateral side to raised limb during inspiration.

Exercise 4 - Same as the 1st associated with the shoulders abduction to the water surface during deep inspiration.

Phase 3: Expiratory Muscles Strengthening - All the exercises were performed requesting a maximum expiration with close lip, and water at the shoulder level.

Exercise 1 - It was performed with underarm support on a float, reproducing with the lower limbs the pedaling movements, leaning on the pool edge.

Exercise 2 - Still supported on the pool edge, pelvic retroversion movements with the approach of both knees to the trunk.

Exercise 3 - With the previous positioning, keeping both knees close to abdomen, with pelvic retroversion and abdominal musculature contraction, performed the pelvic lateral rotation.

Exercise 4 - with the anterior position was performed lateral inclination hip, with knees and legs accompanying the movement.

The first two phases were performed in the same way as LG without any adaptation. At 3rd phase, the participant position was altered, the exercises being performed in the dorsal decubitus (DD), but still following the same movements:

Exercise 1 - in hip DD and flexed knees, the subjects reproduced pedaling movements. 
Exercise 2 - DD, pelvic retroversion performed an approximation of both knees to the trunk.

Exercise 3 - DD, hip flexion and left knee (L), foot $\mathrm{L}$ supported to the ground, while the right leg (R) is positioned with the heel above the knee of the supporting leg. The upper limb $\mathrm{R}$ is positioned along the trunk, while the upper limb $\mathrm{L}$ is flexed with the hand behind the head. Bending with trunk rotation should be performed by approaching the elbow $\mathrm{L}$ of the knee R during exhalation.

Exercise 4 - perform the same previous exercise by changing the side.

Exercises were performing twice a week ( 40 minutes each) during one month. The therapeutic objective and exercise sequence were the same for both groups, the only difference was water-immersion.

Statistical analysis was performed using the Statistical Package for the Social Sciences (SPSS) software version 20.0. The data normality was verified through the Shapiro-Wilk Test. Values are presented in median (minimum value - maximum value). For the intergroup comparison, the Mann-Whitney test was used and the Wilcoxon test was used for pre and post training intragroup comparisons (significance level was $\mathrm{p}<0.05$ ).

\section{Results}

At first, 64 elderly women were enrolled in the PELC, but only 45 were presented for the initial evaluation. After, 13 subjects were excluded ( 3 = not having the minimum height, $7=$ smokers, 3 = hydrophobia). Therefore, 32 subjects from
Programa de Esporte e Lazer na Cidade (PELC) composed the sample, considering the inclusion criteria, and they were randomized in two groups: Hydro group $(n=16)$ and Land-Based group $(n=16)$. On the first protocol day, eight subjects did not attend and they were excluded. During the treatment weeks, nine subjects were excluded (lack of adherence). Finally, 15 subjects were divided in two paired groups ( $p>0.05$ ), being seven in the land-based group and eight in the hydro group (Table 1).

Table $\mathbf{1}$ - Study sample characteristics after intervention group randomization

\begin{tabular}{lcc}
\hline \multirow{2}{*}{ Variables } & \multicolumn{2}{c}{ Basal } \\
\cline { 2 - 3 } & GH & GS \\
\hline Age (years) & $61(60-70)$ & $62(60-70)$ \\
Body mass $(\mathrm{kg})$ & $70(50-91)$ & $74(54-93)$ \\
Height $(\mathrm{m})$ & $1.56(1.48-1.68)$ & $1.56(1,49-1,65)$ \\
BMI $\left(\mathrm{kg} / \mathrm{m}^{2}\right)$ & $29(22-35)$ & $29(25-36)$ \\
Baecke & $3.5(2.9-7.8)$ & $3.1(2.5-7.2)$ \\
\hline
\end{tabular}

Note: BMI = Body Mass Index. Mann Whitney Test.

Pulmonary functional capacity assessment data of both groups are presented in Table 2. After the treatment period, LG presented a statistically significant increase in FEF $25-75 \%(p=0.04)$. Respiratory muscle strength evaluation by pre and post intervention manovacuometry showed that HG improved the MEP values ( $\mathrm{p}=0.007)$. The MIP did not present changes ( $p>0.05)$, as did the MIP and MEP data in the LG (Table 2). No difference was observed between groups in terms of maximal respiratory pressures and spirometric parameters.

Table 2 -Pulmonary functional capacity descriptive analysis of both group pre and post intervention

\begin{tabular}{lcccc}
\hline \multirow{2}{*}{ Variables } & \multicolumn{3}{c}{ Basal } & \multicolumn{2}{c}{ Post 4 weeks } \\
\cline { 2 - 5 } & HG & LG & HG & LG \\
\hline FEV1 (\% predicted) & $86(76-107)$ & $81(73-141)$ & $99(78-112)$ & $86(74-127)$ \\
FVC (\% predicted) & $81(73-128)$ & $88(75-122)$ & $89(74-110)$ & $66(70-103)$ \\
VEF1/FVC (\% predicted) & $93(80-99)$ & $92(80-97)$ & $91(80-95)$ & $97(83-99)$ \\
PEF (\% predicted) & $76(61-95)$ & $77(56-105)$ & $92(62-144)$ & $89(86-123)$ \\
FEF 25-75\% (\% predicted) & $94(44-111)$ & $84(73-114)$ & $90(55-122)$ & $91(74-153)^{*}$ \\
MEP (cmH20) & $60(30-100)$ & $60(50-100)$ & $75(40-110)^{*}$ & $60(45-110)$ \\
MIP(cmH20) & $90(50-110)$ & $60(40-150)$ & $85(50-130)$ & $70(60-150)$ \\
\hline
\end{tabular}

Note: FEV1 = Forced Expiratory Volume in one second; FVC = Forced Vital Capacity; FEV1 / FVC = Relationship FEV1 / FVC; PEF = Peak of Expiratory Flow; FEF 25-75\% = Forced Expiratory Flow between 25 and $75 \%$ of the FVC; MEP = expiratory maximal pressures; MIP $=$ inspiratory maximal pressures. ${ }^{*} p<0,05$. Mann Whitney test for intergroup analysis and Wilcoxon test for intragroup analysis. 
Table 3 shows the physical functional capacity data of both groups. About 6MWT, HG presented lower HR values after four-week training $(p=0.006)$. The same was observed in relation to Diastolic Blood Pressure (DBP), there was a reduction in pre-pressure $(p=0.006)$ and post-test $(p=0.041)$ values. There was no statistically significant difference in relation to other variables in intra and intergroup analysis. There was no statistical difference regarding PGS after four-week intervention in both groups, as well as in intergroup analysis.

Table 3 - Physical functional capacity data of both intervention groups

\begin{tabular}{|c|c|c|c|c|}
\hline \multirow{2}{*}{ Variables } & \multirow{2}{*}{$\begin{array}{c}\text { Basal } \\
\text { HG }\end{array}$} & \multicolumn{3}{|c|}{$\begin{array}{l}\text { Post } 4 \\
\text { weeks }\end{array}$} \\
\hline & & LG & $H G$ & LG \\
\hline HR initial (bpm) & $\begin{array}{c}72 \\
(43-101)\end{array}$ & $\begin{array}{c}77 \\
(60-109)\end{array}$ & $\begin{array}{c}64 \\
(43-74)^{*}\end{array}$ & $\begin{array}{c}65 \\
(54-80)\end{array}$ \\
\hline HR final (bpm) & $\begin{array}{c}76 \\
(70-147)\end{array}$ & $\begin{array}{c}74 \\
67-112)\end{array}$ & $\begin{array}{c}71 \\
(42-90)\end{array}$ & $\begin{array}{c}80 \\
(68-96)\end{array}$ \\
\hline $\begin{array}{l}\Delta \text { HR final-1 min } \\
(\mathrm{bpm})\end{array}$ & $\begin{array}{c}-2 \\
(-14-14)\end{array}$ & $\begin{array}{c}1 \\
(-4-13)\end{array}$ & $\begin{array}{c}-7 \\
(-12-24)\end{array}$ & $\begin{array}{c}-10 \\
(-30-5)\end{array}$ \\
\hline $\begin{array}{l}\Delta \mathrm{HR} \text { final-2 min } \\
(\mathrm{bpm})\end{array}$ & $\begin{array}{c}-2 \\
(-16-12)\end{array}$ & $\begin{array}{c}2 \\
(-5-7)\end{array}$ & $\begin{array}{c}-8 \\
(-13-9)\end{array}$ & $\begin{array}{c}-16 \\
(-31-6)\end{array}$ \\
\hline RR initial (ipm) & $\begin{array}{c}17 \\
(11-23)\end{array}$ & $\begin{array}{c}16 \\
(14-23)\end{array}$ & $\begin{array}{c}15 \\
(12-21)\end{array}$ & $\begin{array}{c}18 \\
(13-25)\end{array}$ \\
\hline RR final (ipm) & $\begin{array}{c}18 \\
(13-23)\end{array}$ & $\begin{array}{c}19 \\
(14-25)\end{array}$ & $\begin{array}{c}18 \\
(14-23)\end{array}$ & $\begin{array}{c}19 \\
(14-23)\end{array}$ \\
\hline Sp02 initial (\%) & $\begin{array}{c}98 \\
(90-99)\end{array}$ & $\begin{array}{c}98 \\
(94-99)\end{array}$ & $\begin{array}{c}97 \\
(94-98)\end{array}$ & $\begin{array}{c}97 \\
(92-99)\end{array}$ \\
\hline Sp02 final (\%) & $\begin{array}{c}99 \\
(96-99)\end{array}$ & $\begin{array}{c}98 \\
(97-99)\end{array}$ & $\begin{array}{c}98 \\
(97-99)\end{array}$ & $\begin{array}{c}98 \\
(93-99)\end{array}$ \\
\hline $\begin{array}{l}\text { SBP initial } \\
(\mathrm{mmHg})\end{array}$ & $\begin{array}{c}140 \\
(100-160)\end{array}$ & $\begin{array}{c}140 \\
(100-150)\end{array}$ & $\begin{array}{c}135 \\
(90-190)\end{array}$ & $\begin{array}{c}120 \\
(110-190)\end{array}$ \\
\hline SBP final $(\mathrm{mmHg})$ & $\begin{array}{c}145 \\
(110-160)\end{array}$ & $\begin{array}{c}120 \\
(100-200)\end{array}$ & $\begin{array}{c}155 \\
(90-190)\end{array}$ & $\begin{array}{c}130 \\
(90-230)\end{array}$ \\
\hline $\begin{array}{l}\text { DBP initial } \\
(\mathrm{mmHg})\end{array}$ & $\begin{array}{c}90 \\
(70-110)\end{array}$ & $\begin{array}{c}80 \\
(60-100)\end{array}$ & $\begin{array}{c}80 \\
(50-100)^{*}\end{array}$ & $\begin{array}{c}80 \\
(70-100)\end{array}$ \\
\hline DBP final (mmHg) & $\begin{array}{c}85 \\
(70-110)\end{array}$ & $\begin{array}{c}70 \\
(60-100)\end{array}$ & $\begin{array}{c}85 \\
(50-90)^{*}\end{array}$ & $\begin{array}{c}80 \\
(60-100)\end{array}$ \\
\hline BORG & $2(0-3)$ & $3(2-3)$ & $2(0-3)$ & $3(1-4)$ \\
\hline $\begin{array}{l}\text { Distance 6MWT } \\
\text { (m) }\end{array}$ & $\begin{array}{c}458 \\
(403-530)\end{array}$ & $\begin{array}{c}445 \\
(224-520)\end{array}$ & $\begin{array}{c}467 \\
(384-520)\end{array}$ & $\begin{array}{c}442 \\
(225-487)\end{array}$ \\
\hline PGS R & $\begin{array}{c}24 \\
(21-30)\end{array}$ & $\begin{array}{c}23 \\
(11-25)\end{array}$ & $\begin{array}{c}26 \\
(23-32)\end{array}$ & $\begin{array}{c}22 \\
(16-31)\end{array}$ \\
\hline PGS L & $\begin{array}{c}22 \\
(10-33)\end{array}$ & $\begin{array}{c}20 \\
(10-26)\end{array}$ & $\begin{array}{c}24 \\
(13-35)\end{array}$ & $\begin{array}{c}18 \\
(11-29)\end{array}$ \\
\hline
\end{tabular}

Note: $\mathrm{HR}=$ Heart Rate; $\mathrm{RR}=$ Respiratory Rate Sp02 $=$ Peripheral saturation of $02 ; \mathrm{SBP}=$ Systolic Blood Pressure; DBS = Diastolic Blood Pressure; PGS R = Palmar Grip Strength Right; PGS L= Palmar Grip Strength Left.

\section{Discussion}

This study showed that after four-week training there was a MEP improvement, as well as in the elderly women cardiovascular variables submitted to aquatic exercise protocol.

The aquatic exercise practice causes different neuromuscular and cardiorespiratory responses compared to land-based environment. These responses are associated with some aquatic physical characteristics such as buoyancy, density, hydrostatic pressure and thermodynamics $[6,22]$.

Among the hydrotherapeutic exercise benefits are injury risk reduction, maximal oxygen consumption (V02max) improvement and increased strength and respiratory muscles resistance $[6,23]$.

Ide et al. [9] developed an elderly physical therapy program by emphasizing the inspiratory muscles in the aquatic and land-based environment, three-time a week for 10 weeks, comparing their RMS effects. Aquatic group (pre $=-92$, post $=-100$ ) presented a significant MIP increase when compared to LG (pre $=-86$, post $=-88$ ). In this study, no statistically significant increase in inspiratory muscle strength after short-term training in different environments was observed, which may be justified by the fact that the exercise protocol used did not prioritize the inspiratory muscles as in the study cited, as well as by the some elderly women presented normal MEP and MIP values [9]. The respiratory muscle training protocol was based on the model developed by Pereira [21]. For this, a crossover was performed, where the two groups performed the protocol both in the water and in the land, with one-week interval. There was a MIP increase in the 2nd water intervention, and the MEP in the first land intervention.

MEP values increased after four-week water intervention ( $p=0.007)$, which does not support previous studies $[9,24]$ in which no MEP change was observed after physical training in elderly. However, the rectus abdominis muscle, which acting on forced expiration, is more superficial and responding more effectively to muscle contraction due to water temperature [20]. Different types of respiratory muscle training environment effect on PGS, the same skeletal muscle function estimation, have been evaluated and have been used to evaluate global muscle strength [25].

This study did not observe a statistically significant elderly PGS increase in both groups, although our data 
suppose a clinical difference in the same. In a previous study [26], it was verified the PGS increase after landbased exercise program $(\mathrm{p}<0.05)$. Considering the muscular strength importance in elderly, whether in the upper limbs to perform ADL or in the lower limbs acting in the gait, keeping this strength is already a sign that the exercises were effective [27].

Regarding the spirometric variables, after the intervention, both groups did not present significant changes in FVC, FEV1, FEV1 / FVC and PEF. Subjects present pulmonary function integrity with normal values for these parameters, in according to Grossi [28]. But, here, there was a significant FEF $25-75 \%$ increase ( $p=0.04)$ in $L G$, according to Durante et al. [29], after the six-week land-based exercise period there was a considerable FEF 25-75\% improvement. This may be an increase consequence in the respiratory muscles strength, which results in a better system capacity, thus generating greater velocity and expiratory flow through the airways [30].

Physical functional capacity is an important marker of the general health status in elderly and was evaluated by 6MWT. However, no statistically significant difference was observed in the 6MWT distance after intervention. Alves' study [31], with three-month duration, aquatic protocol divided into: 1. Stretching, 2. Aerobic exercises (arms and legs movement), 3. Localized exercises (Strength/ resistance) and 4. Relaxation (slow walking). After the protocol application, there was a distance increase, demonstrating that global exercises and a longer training period increased aerobic capacity from 10 to $40 \%$ in the active elderly. In this study, elderly were classified as low physical activity level. Therefore, it is believed that the physical activity level was not a limiting factor for our findings.

In relation to final cardiovascular alterations, $\mathrm{HG}$ presented lower HR ( $\mathrm{p}=0.006)$ and DBP values, there was a reduction in the pre-test $(\mathrm{p}=0.006)$ and posttest $(p=0.041)$ values of six-minute walking. These findings suppose positive physical exercise protocol effects on cardiovascular adaptations to exercise. Candeloro and Caromano [2] observed a significant DBP reduction after physical exercise program.

Among these study limitations, we can cite the sample size, due to adhesion lack. But, this is a study with great methodological rigor that evidenced the short-term positive aquatic training effects.

\section{Conclusion}

This study results in the experimental conditions used suggest that the short-term aquatic respiratory exercises protocol has positive MEP effects and cardiovascular parameters in elderly. Also, the immersion influence in heated water on the expiratory muscular force generates possibilities of using this resource as an alternative to respiratory muscle training protocols in a differentiated environment.

\section{Referências}

1. Pícoli TS, Figueiredo LL, Patrizzi LJ. Sarcopenia e envelhecimento. Fisioter. Mov. 2011;24(3):455-62.

2. Candeloro JM, Caromano FA. Efeito de um programa de hidroterapia na flexibilidade e na força muscular de idosas. Rev Bras Fisioter. 2007;11(4):303-9.

3. Freitas ERFS, Araújo ECLS, Alves KS. Influência do tabagismo na força muscular respiratória em idosos. Fisioter Pesqui. 2012;19(4):326-31.

4. Albuquerque IM, Emmanouilidis A, Ortolan T, Cardoso DM, Gass R, Jost RT, et al. Capacidade funcional submáxima e força muscular respiratória entre idosas praticantes de hidroginástica e dança: um estudo comparativo. Rev Bras Geriatr Gerontol. 2013;16(2): 327-36.

5. Ruivo S, Viana P, Martins C, Baeta C. Effects of aging on lung function. A comparison of lung function in healthy adults and the elderly. Rev Port Pneumol. 2009;15(4):629-53.

6. Ide MR, Caromano FA, Dip MAVB, Guerino MR. Exercícios respiratórios na expansibilidade torácica de idosos: exercícios aquáticos e solo. Fisioter Mov. 2007;20(2):33-40.

7. Salicio VMM, Shimoya-Bittencourt W, Silva ETB, Rodrigues NEL, Salicio, MA. Função Respiratória em Idosos Praticantes e não Praticantes de Hidroterapia. Cient Cienc Biol Saude. 2015;17(2):107-12.

8. Vaz RCR. Envelhecimento e atividade física: influências na qualidade de vida [undergraduate thesis]. Goianésia: Universidade Federal de Goiás; 2014. 
9. Ide MR, Belini MAV, Caromano FA. Effects of an aquatic versus non-aquatic respiratory exercise program on the respiratory muscle strength in healthy aged persons. Clinics (Sao Paulo). 2005;60(2):151-8.

10. Voorrips LE, Ravelli AC, Dongelmans PC, Deurenberg P, Van Staveren WA. A physical activity questionnaire for the elderly. Med Sci Sports Exerc. 1991;23(8):974-9.

11. Sneath PHA, Sokal RR. Numerical Taxonomy. The Principle and Practice of Numerical Classification. San Francisco: W.H. Freeman and Company; 1973. 573 p.

12. Pereira CAC. Espirometria. In: Pereira CAC, Neder JA, editors. Diretrizes para testes de função pulmonar.J Bras Pneumol. 2002;28(Suppl 3):S1-82.

13. Knudson RJ, Slatin RC, Lebowitz MD, Burrows B. The maximal expiratory flow-volume curves. Normal standards variability and effect of age. Am Rev Respir Dis $1976 ; 113: 587-600$

14. Badr C, Elkins MR, Ellis ER. The effect of body position on maximal expiratory pressure and flow. Aust J Physiother. 2002;48(2):95-102.

15. Neder JA, Andreoni S, Lerario MC, Nery LE. Reference values for lung function tests. II. Maximal respiratory pressures and voluntary ventilation. Braz J Med Biol Res. 1999;32(6):719-27.

16. Souza RB. Pressões respiratórias estáticas máximas. J Pneumol. 2002;28( Suppl 3):S155-65.

17. Silveira JM, Gastaldi AC, Boaventura CM, Souza HC. Treinamento de músculos inspiratórios em pacientes com quadriplegia. J Bras Pneumol. 2010;36(3):313-9.

18. ATS Committee on Proficiency Standards for Clinical Pulmonary Function Laboratories. ATS statement: guidelines for the six-minute walk test. Am J Respir Crit Care Med. 2002;166(1):111-7.

19. Borg GA. Psychophysical bases of perceived exertion. Med Sci Sports Exerc. 1982;14(5):377-81.

20. Schlüssel MM, Anjos LA, Kac G. A dinamometria manual e seu uso na avaliação nutricional. Rev Nutr. 2008;21(2):233-5.

21. Pereira KS. Estudo comparativo dos exercícios respiratórios em piscina aquecida para asmáticos graves e moderados: impacto de uma sessão [master's thesis]. São Paulo: Universidade de São Paulo; 2005.
22. Silva EM, Kruel LFM. Caminhada em ambiente aquático e terrestre: revisão de literatura sobre a comparação das respostas neuromusculares e cardiorrespiratórias. Rev Bras Med Esporte. 2008;14(6):553-6.

23. Teixeira CS. Hidroginástica na reabilitação vestibular de idosos com queixas de tontura [master's thesis]. Santa Maria: Universidade Federal de Santa Maria; 2008.

24. Fagundes AA, Silva RF. Efeitos da imersão em água aquecida sobre o sistema respiratório. Fisioter Mov. 2006;19(4):113-8.

25. Martin FG, Nebuloni CC, Najas MS. Correlação entre estado nutricional e força de preensão palmar em idosos. Rev Bras Geriatr Gerontol. 2012;15(3):493-504.

26. Costa EL, Bastos Filho PSC, Moura MS, Sousa TS, Lemos A, Pedrosa MAC. Efeitos de um programa de exercícios em grupo sobre a força de preensão manual em idosas com baixa massa óssea. Arq Bras Endocrinol Metab. 2012;56(5):313-8

27. Fidelis LT, Patrizzi LJ, Walsh IAP. Influência da prática de exercícios físicos sobre a flexibilidade, força muscular manual e mobilidade funcional em idosos. Rev Bras Geriatr Gerontol. 2013;16(1):109-16.

28. Grossi RTD. Avaliação da função pulmonar após programa de condicionamento físico à curto prazo em idosas com aumento da gordura abdominal. Curitiba PR. Monografia [certificate program thesis]. Curitiba: Universidade Tuiuti do Paraná; 2002.

29. Durante A, Rodigheri A, Rockenbach CWF, Pimentel GL, Leguisamo CP, Calegari L. Treinamento muscular inspiratório melhora a força muscular respiratória e o pico de fluxo expiratório em idosas hipertensas. Conscientiae Saude. 2014;13(3):364-71.

30. Freitas FS, Parreira VF, Ibiapina CC. Aplicação clínica do pico de fluxo da tosse: uma revisão de literatura. Fisioter Mov. 2010;23(3):495-502.

31. Alves RV, Mota J, Costa MC, Alves JGB. Aptidão física relacionada à saú- de de idosos: influência da hidroginástica. Rev Bras Med Esporte. 2004;10(1):31-7

Received in $06 / 29 / 2017$ Recebido em 29/06/2017

Approved in 11/07/2017 Aprovado em 07/11/2017 